\title{
CORRELATION OF GLACIAL DEPOSITS OF THE HURON, LAKE MICHIGAN AND GREEN BAY LOBES IN MICHIGAN AND WISCONSIN
}

\author{
Donald F. Eschman \\ Department of Geological Sciences, University of Michigan, Ann Arbor, Michigan, U.S.A. \\ and \\ David M. Mickelson \\ Department of Geology and Geophysics, University of Wisconsin, Madison, Wisconsin, U.S.A.
}

\section{INTRODUCTION}

Michigan and eastern Wisconsin were glaciated several times during the Pleistocene. Ice erosion overdeepened river valleys in the weaker units of the sequence of sedimentary rocks now exposed as a result of structural basining. Glacial erosion led to development of the three relatively deep bedrock basins, now occupied by Lakes Huron, Michigan, and Superior. As a result, whenever an ice margin crossed the area it had a lobate form, with ice tongues extending relatively far south in the bedrock basins while much of the area between the lobes was ice-free. Lobe margins within the basins terminated in proglacial lakes. The ice lobes of importance in the area are (a) the Huron lobe and its Saginaw sublobe, (b) the Lake Michigan lobe, and (c) the Green Bay lobe (Fig. 1). The granulometry and mineralogy of the drift related to each lobe reflect the nature of both the bedrock and older surficial units upice.

In much of the area, the glacially-related deposits are over $30 \mathrm{~m}$ thick, and in some places the thickness is more than $300 \mathrm{~m}$. The surface deposits nearly everywhere are late Wisconsin in age, and relatively little is known of the glacial history of the area prior to that time. Formal names have not been established for lithostratigraphic units in Michigan, and most units in Wisconsin have only recently been formally defined (Mickelson et al., 1984).

\section{PRE-WISCONSIN DEPOSITS}

Recent subsurface stratigraphic work in southeastern Wisconsin west of (outside) the Wisconsin drift border has resulted in recognition of four tills of probable preWisconsin age (Schneider, 1983; Mickelson et al., 1984). The three older tills are facies of three members of the Walworth Formation: the Foxhollow, Allens Grove, and Clinton Members, from oldest to youngest. The gray loamy Foxhollow Member occurs only in the subsurface, in bedrock valleys. The pink sandy Allens Grove Member also is known only in the subsurface. It is correlated with the Argyle Till Member of the Winnebago Formation in Illinois (see Johnson, this volume). The Clinton Member of the Walworth Formation occurs at the surface in a $1500 \mathrm{~km}^{2}$ area in southernmost Wisconsin. The sandy loam till is light yellowish brown to light brown in color, with a noticeable pink tint in places, particularly when dry.

Thus far, evidence of pre-Wisconsin glaciation has been found only at one locality north of the late Wisconsin boundary in Wisconsin. In a gravel pit about $10 \mathrm{~km}$ east of (inside) the outer limit of late Wisconsin deposits in southern Wisconsin (Fig. 1), a welldeveloped soil, correlated with the Sangamon soil in Illinois, is buried by late Wisconsin till (Schneider and Follmer, 1983a, b). In exposures no longer available the soil appeared to be developed in a thin layer of till that capped thick outwash sand and gravel. Glacial deposits of pre-Wisconsin age have not been identified in Michigan. Pre-Wisconsin tills outside the late Wisconsin border in Wisconsin and Illinois are discussed by Johnson (this volume).

\section{EARLY AND MIDDLE WISCONSIN DEPOSITS}

On the basis of analysis of many water well logs recording organic deposits beneath relatively thick glacial deposits of Wisconsin age, Rieck and Winters (1982) recognize several areas in the Southern Peninsula of Michigan, in the region glaciated by the Huron and Lake Michigan ice lobes (Fig. 1), in which such deposits occur at more than one elevation. This suggests that there are several paleosurfaces, each interpreted by them as representing either an interglaciation or a long interstade. The fact that most of these paleosurfaces are below the modern levels of Lake Michigan and Lake Huron suggests that the two basins were occupied by lakes lower than the present lakes on more than one occasion prior to late Wisconsin glaciation. The lowest of the paleosurfaces may be graded to a lake level controlled by the $120 \mathrm{~m}$ bedrock 


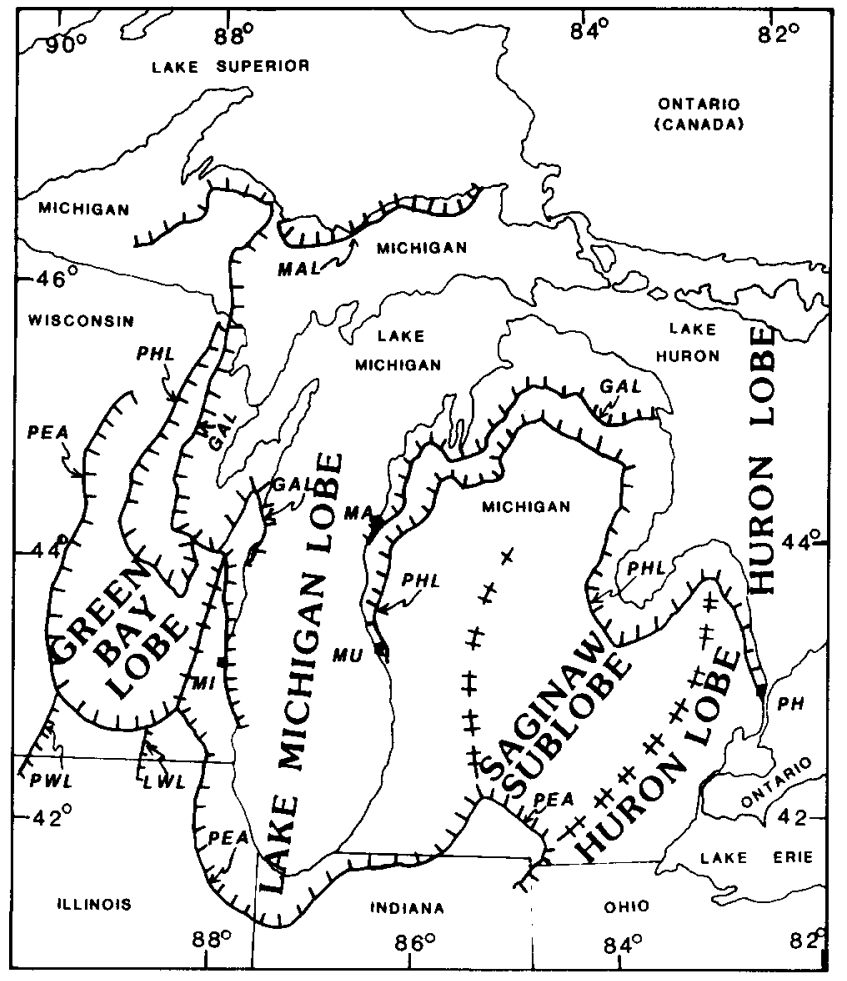

FIG. 1. Index map showing glacial lobes and sublobes and drift limits.

$\begin{array}{ll}\text { MA } & \text { Manistee, Michigan } \\ \text { MI } & \text { Milwaukee, Wisconsin } \\ \text { MU } & \text { Muskegon, Michigan } \\ \text { PH } & \text { Port Huron, Michigan } \\ \text { GAL } & \text { Greatlakean advance limit } \\ \text { LWL } & \text { Late Wisconsin drift limit } \\ \text { MAL } & \text { Marquette advance limit } \\ \text { PEA } & \text { Limit of post-Erie interstade advance } \\ \text { PHL } & \text { Port Huron stade advance limit } \\ \text { PWL } & \text { Limit of pre-Wisconsin glaciation }\end{array}$

threshold in the Trent lowland in Ontario, reported by White and Karrow (1971).

The oldest glacial deposit recognized thus far in Michigan is an unnamed till that underlies the John Ball State Park organic bed at Grand Rapids (Zumberge and Benninghoff, 1969). The organic bed yielded ${ }^{14} \mathrm{C}$ ages of $>39,900$ (I-4900), $>40,000$ (W-1292, W-1294, $\mathrm{W}-1300)$, and $>51,000 \mathrm{BP}(\mathrm{GrN}-4614)$, and pollen spores and plant macrofossils are similar to those in the middle Wisconsin Port Talbot II interstadial deposits (Dreimanis et al., 1966; Berti, 1975) in Ontario, Canada. The till beneath the organic bed is unweathered, and therefore it is inferred to antedate deposition of the organic sediment by only a short interval of time. It is inferred to be early Wisconsin or middle Wisconsin in age, although a pre-Wisconsin age is not precluded (Chart 1).

Along Mill Creek, a tributary of the Black River near Port Huron, Michigan (Fig. 1), three tills overlie an organic bed containing pollen (spruce and pine dominant) and macrofossils that are similar to those in the Port Talbot II beds. The organic bed yielded a ${ }^{14} \mathrm{C}$ age of 48,300 $\pm 800 \mathrm{BP}$ (QL-1215; Eschman, 1980). Another organic horizon containing logs that have been dated 45,800 \pm 700 BP (QL-963; Stuiver et al., 1978) outcrops in the bed of Pine River in the northwestern part of the Southern Peninsula of Michigan. Southwest of Grand Rapids, along the shore of Lake Michigan, reworked wood and peat in lake sediment between two tills yielded dates of $37,150 \pm 540$ (Beta-3311), 38,130 \pm 740 (Beta-3310), $>37,000(\mathrm{GX}-8193)$ and $>48,000$ (ISGS-948) BP (Gephart et al., 1982, 1983). The locations of these organic deposits require that much of the Southern Peninsula of Michigan was ice-free during at least part of middle Wisconsin time.

In southeastern Wisconsin, the Capron Member of the Zenda Formation, the continuation of the Capron Till Member of the Winnebago Formation in Illinois, overlies tills of the Walworth Formation and it is at the surface in a north-south zone only a few $\mathrm{km}$ wide between the area of outcrop of the Illinoian Walworth Formation to the west and the late Wisconsin deposits to the east. The light brown to brown till of the Capron Member consists of a lower silty phase and an upper, more sandy phase. As yet there is no ${ }^{14} \mathrm{C}$ control for the Capron Till in either Illinois or Wisconsin, but it is inferred to represent an early Wisconsin or middle Wisconsin advance of the Lake Michigan ice lobe (Johnson, this volume).

\section{LATE WISCONSIN DEPOSITS}

Near Port Huron, Michigan, a relatively loose, sandy till, the Mill Creek Till, is separated from the older 48.3 ka BP organic bed noted above by nearly $4 \mathrm{~m}$ of lacustrine and fluvial sand and gravel. Elsewhere in the Black River drainage, the Mill Creek Till is overlain by a lacustrine unit and, in turn, by the very compact Sanilac Till that is interpreted to have been deposited during the maximum Late Wisconsin advance that began around $24 \mathrm{ka}$ BP. In the Grand Rapids area, a $\log$ in gravel interpreted to be glacial outwash yielded a date of 33,000 \pm 1800 BP (I-5078; Eschman, 1980).* The Mill Creek Till and the outwash near Grand Rapids here are considered to represent a simultaneous advance of the Huron lobe and Saginaw sublobe ice margins, although two separate ice advances of different ages may be represented by the deposits.

Buried organic materials exposed along the shores and also in the subsurface a short distance inland from both Lake Michigan and Lake Huron yielded ${ }^{14} \mathrm{C}$ ages between 25 and $31 \mathrm{ka} \mathrm{BP}$ (Chart 1). The lake deposits between the Mill Creek Till and the overlying tills northwest of Port Huron, Michigan, mentioned above, coarsen upward markedly. In at least one place they are marked by well-developed ball and pillow structures, suggesting that they were deposited in a proglacial lake that formed during the advance of the late Wisconsin ice margin to its maximum position (Eschman, 1982).

\footnotetext{
* The wood was decayed and contaminated by modern mold and fungus (Buckley, J. and Willis, E.H., 1972, Isotopes' radiocarbon measurements IX. Radiocarbon, 14, p. 118); consequently, the ${ }^{14} \mathrm{C}$ age may be unreliable and the gravel may be early Wisconsin in age - Editors.
} 
These data together suggest that much of the Southern Peninsula of Michigan was ice-free prior to $24 \mathrm{ka}$ BP.

The oldest Huron lobe till overlying the Mill Creek Till is the sandy, very compact Sanilac Till. An unnamed, very compact till encountered at depth in much of southeastern Michigan probably is correlative with the Sanilac. The till overlying the dated organic bed along the Lake Michigan shore also may be equivalent to the Sanilac Till, although Gephart et al. (1983) suggested that it is younger than the Sanilac Till.

Two Lake Michigan lobe tills are recognized along the west side of Lake Michigan in southeastern Wiscon$\sin$. The lower till is the pinkish-gray to violet-gray Tiskilwa Member of the Zenda Formation in Wisconsin and the Tiskilwa Till Member the Wedron Formation in Illinois (see Johnson, this volume). The upper till, included in the New Berlin Formation in Wisconsin, is yellowish brown. Within the Green Bay lobe area, the Liberty Grove and Mapleview Members of the Horicon Formation are recognized on the east and west sides of the Lake Michigan lobe area, respectively. The till of both members of the Horicon Formation is dull reddish brown and sandy. No dates are available for the initial advance of the Green Bay lobe ice margin, but the advance probably was roughly synchronous with the advance of the Lake Michigan lobe margin. Near the outer limit of the Horicon Formation, lake-bottom dates of 12,800 $\pm 125 \mathrm{BP}$ (WIS-1004) and 12,520 \pm 160 BP (WIS-1075) suggest that ice may have remained near its maximum extent until perhaps $13 \mathrm{ka}$ BP (Maher, 1981).

Stratigraphic evidence of the Erie interstade (Chart 1) for the most part is lacking in Michigan and eastern Wisconsin. One exception is the area northwest of Port Huron, Michigan, where the interstade is represented by thin lacustrine sand and silt. A second exception is in the Milwaukee, Wisconsin, area. Here there is evidence in the subsurface for a proglacial lake that is interpreted to have occupied the southern end of the Lake Michigan basin during the Erie interstade (Need, 1983; Schneider and Need, 1983). Perhaps one of the inter-till lacustrine units exposed along the east shore of Lake Michigan (Taylor, 1977; Gephart et al., 1982, 1983) represents a correlative proglacial lake in the Lake Michigan basin. Evidence of significant weathering during this interval has not been found and no radiocarbon dates have been obtained from sediments deposited during the interstade.

The post-Erie interstade readvance of the Huron lobe ice margin is represented by the silty clay loam Fisher Road Till. In the vicinity of its type locality in Michigan, the Fisher Road Till consists of two till members that are separated by a thin lacustrine unit that is interpreted to represent the lowest phase of Glacial Lake Maumee (Eschman, 1978). The upper till member (the Avoca Till of Eschman, 1978) has been traced northwestward, and it was deposited as a result of a relatively minor readvance of the ice margin (Burgis and Eschman, 1980). The Fisher Road ice advance diverted the drainage of Glacial Lake Maumee, via the Imlay City-North Branch channel, across the Thumb interlobate area to the Saginaw Lowland, and then by way of the Glacial Grand River to Glacial Lake Chicago, as proposed by Leverett and Taylor (1915). The lower unit of the Fisher Road Till is correlated with the Powell Till in the Scioto sublobe area of the Huron-Erie lobe in Ohio (see Fullerton, this volume).

The margin of the Saginaw sublobe of the Huron lobe (Fig. 1) did not advance as far as did the main Huron lobe ice margin after the Erie interstade, and an ice-free area extended about $100 \mathrm{~km}$ southwestward from the margin of the sublobe between the Huron lobe (to the southeast) and the Lake Michigan lobe (to the west) (Zumberge, 1960). The outermost deposits of the Saginaw sublobe are poorly sorted, coarse sand and gravel characterized by hummocky topography that indicates stagnation of the outer marginal zone on a bedrock high. Up-ice from this stagnation zone the till has a silty clay loam texture. Unnamed tills in the Lake Michigan lobe area in Michigan are clayey, with clay content increasing and pebble frequency decreasing as the present lake shore is approached. The gray, silty Wadsworth Till Member of the Wedron Formation is the equivalent till in northern Illinois and beneath Lake Michigan (Lineback et al., 1974).

Multiple till units on the west side of the Lake Michigan lobe in Wisconsin that were deposited as a result of the post-Erie interstade readvance are included in the Oak Creek Formation. Till of this formation typically is gray and clayey. Till with similar characteristics was not deposited in the Green Bay lobe area, but reddish-brown, sandy till in the upper part of the Horicon Formation probably is the same age as the tills in the Oak Creek Formation (Chart 1).

The Mackinaw interstade in the Lake Huron basin and the Saginaw Lowland was represented by three proglacial lake phases that collectively are referred to as Glacial Lake Arkona (Leverett and Taylor, 1915). Each lake phase was continuous from the Saginaw Lowland to the Lake Erie basin. All three lake phases drained westward, via the Glacial Grand Valley, to the Lake Michigan basin, indicating that ice covered the Niagara Falls region in New York when the lakes were in existence. However, there is increasing evidence that ice margins retreated far enough at some time during the Mackinaw interstade to open lower outlets to the east. Fullerton (1971) found evidence of proglacial lake drainage eastward through the Mohawk Valley in New York during this time interval, and fragmentary evidence in the Lake Huron basin indicates that the ice margin there retreated at least as far north as Goderich, Ontario (Dreimanis, 1969). Also, some evidence suggests that there was drainage between Georgian Bay and the Lake Ontario basin, via the Trent Lowland in Ontario, during part of the interstade. Within the Lake Michigan basin there is equivocal evidence of a relatively low lake phase, the Bowmanville level of Bretz (1951), which seemingly requires eastward drainage from the Lake Michigan basin. Radiocarbon dates from the Cheboygan bryophyte bed (Farrand et al., 
1969) are equivocal, but they suggest that the area only $15 \mathrm{~km}$ south of the Straits of Mackinaw may have been ice-free during the Mackinaw interstade. This would have resulted in a relatively low connection between lakes in the Lake Michigan and Lake Huron basins, via the Indian River Lowland. All of these data together suggest that most of the Southern Peninsula of Michigan was free of ice during at least part of the Mackinaw interstade. Drainage from the Lake Superior basin into Lake Michigan also must have occurred at this time, to deliver the red lake sediment that was incorporated by ice during the later glacial readvances.

About 13 ka BP, during the Port Huron stade, the margins of all of the lobes affecting Michigan and Wisconsin readvanced, reestablishing drainage via the Chicago outlet as the eastern outlets and the low lacustrine connections between the several basins were overridden by ice. Separate higher lakes, Lake Whittlesey in the Lake Huron and Lake Erie basins and Lake Saginaw in the Saginaw basin, were formed as a result of this readvance. In general, tills related to the Port Huron readvance are finer-grained than are older tills, probably because of incorporation of sediments that were deposited in the proglacial lakes during the earlier ice margin recession. Light-gray Huron lobe till of this readvance northwest of Port Huron is referred to informally as the Jeddo Till. The correlative unnamed till in the northeastern part of the Southern Peninsula is sandy. The moraine complex that marks the Port Huron readvance in the Lake Huron basin nearly everywhere has a double crest, interpreted to represent two advances separated by minor ice margin retreat. On the Michigan side of the Huron lobe area, no distinction has been made between the tills related to the two advances, but in Ontario, Canada, two tills of Port Huron stadial age have been distinguished (Dreimanis, 1977). In the Saginaw Lowland there are two separate moraines of Port Huron age.

On the Michigan side of the Lake Michigan lobe area two moraine ridges of Port Huron age are separated by an outwash plain. The tills associated with both ridges are reddish brown and silty. Two tills of Port Huron age also are recognized beneath Lake Michigan: the Shorewood (older) and Manitowoc (younger) Till Members of the Wedron Formation (Lineback et al., 1974). The Shorewood Till Member is pinkish-gray, silty clayey till; the Manitowoc Till Member is brown to reddish-brown clayey till.

The Lake Michigan lobe tills of Port Huron age in Wisconsin are the lower three members of the Kewaunee Formation: the Ozaukee, Haven, and Valders Members (Acomb et al., 1982; Mickelson et al., 1984). The reddish-brown to brownish-gray, silty clay Ozaukee Member is the oldest and most extensive. The overlying Haven Member is similar to the Ozaukee Till, but it has a lower clay content. The Two Creeks forest bed at its type locality overlies the Haven Member. The Valders Member contains a thin, distinctly overconsolidated, dull reddish-brown, pebbly sandy silt till unit (the Valders till of Thwaites, 1943). Black (1980), Acomb et al. (1982), and McCartney and Mickelson (1982) discussed the stratigraphy of this area, particularly the stratigraphic position of the Valders till relative to the Two Creeks forest bed. These units are separated by lacustrine deposits along the present shore of Lake Michigan, indicating that lake levels were higher than that of today whenever ice blocked the northern outlet.

In the area of the Green Bay lobe, tills of the Port Huron stade are included in the Kewaunee Formation (Mickelson et al., 1984). Lithologic differences between deposits in the eastern and western parts of the area have resulted in definition of a separate nomenclature for the units in each part. The fact that the two younger glacial advances, represented by members of the Kewaunee Formation, were more extensive than an earlier advance or advances, also represented by members of the same formation, makes correlation of tills on the two sides of the Green Bay lobe area speculative. In the eastern part of the Green Bay lobe area, the Port Huron stade portion of the Kewaunee Formation is divided into the Branch River (older) and Chilton (younger) Members and, in the western part, into the Florence Till (informal), and the Silver Cliff and Kirby Lake Members (McCartney and Mickelson, 1982). A tentative correlation of these members with each other and with Lake Michigan lobe tills is shown in Chart 1. In general, in the area of the Green Bay lobe the characteristics of the till matrices strongly reflect the till provenance (McCartney, 1979). A proglacial lake formed in the Green Bay Lowland during each ice margin advance and recession. Water drained southwestward to the Wisconsin River at the highest level and eastward to Lake Michigan as the ice margin retreated.

During retreat of the Port Huron ice margin, a succession of progressively lower proglacial lakes formed in the Lake Huron and Lake Michigan basins (Leverett and Taylor, 1915; Fullerton, 1980). The shore features of each lake phase have been traced laterally to the outlet of each phase. Because the lake phases indicate the position of the ice margin at a given time, study of the proglacial lake sequence during late Port Huron and post-Port Huron time has added much to our knowledge of deglaciation in the area. During the Two Creeks interstade, about $12 \mathrm{ka}$ to $11.8 \mathrm{ka} \mathrm{BP}$, the Lake Michigan and Huron lobe ice margins retreated far enough to once more allow eastward drainage from the Lake Michigan and Lake Huron basins, via Georgian Bay and the Lake Ontario basin. During this time of lower lake levels red clay was deposited on the lake floors. The subsequent readvance of the Huron, Lake Michigan and Green Bay lobe ice margins during the Greatlakean phase (Evenson et al. 1976) resulted in deposition of clayey red till by all three ice lobes. The Huron lobe Onaway Till is thin and discontinuous (Burgis, 1977; Burgis and Eschman, 1981). The reddish-brown Greatlakean phase tills in the Lake Michigan and Green Bay lobe areas in 
Wisconsin are members of the Kewaunee Formation: the Two Rivers Member in the Lake Michigan lobe area, the Glenmore Member in the eastern part of the Green Bay lobe area, and the Middle Inlet Member in the western part of that lobe area.

Ice margin retreat from the maximum Greatlakean advance position approximately $11.7 \mathrm{ka}$ culminated in a brief unnamed interstade between about 11 and 10.25 $\mathrm{ka}$ BP. A readvance of an ice margin from the Lake Superior basin between about 10,230 and 9,545 BP, known as the Marquette advance, extended a few kilometers into the Northern Peninsula of Michigan, where very clayey red till was deposited (Clayton and Moran, 1982).

\section{REFERENCES}

Acomb, L.I., Mickelson, D.M. and Evenson, E.B. (1982). Til stratigraphy and late glacial events in Lake Michigan lobe in eastern Wisconsin. Geological Society of America Bulletin, 93 289-296.

Berti, A.A. (1975). Paleobotany of Wisconsinan interstadials, eastern Great Lakes region, North America. Quaternary Re search, 5, 591-619.

Black, R.F. (1980), Valders-Two Creeks, Wisconsin, revisited: The Valders Till is most likely post-Twocreekan. Geological Society of America Bulletin, 91, 713-723.

Bretz, JH (1951). The stages of Lake Chicago - Their causes and correlations. American Journal of Science, 249, 401-429.

Burgis, W.A. (1977). Late-Wisconsinan history of northeastern lower Michigan. Ph.D. dissertation, University of Michigan, Ann Arbor, 396 pp.

Burgis, W.A. and Eschman, D.F. (1980). The Imlay Channel and Glacial Lake Maumee [abstract]. Geological Society of America Abstracts with Programs, 12(5), 221.

Burgis, W.A. and Eschman, D.F. (1981). Late-Wisconsinan history of northeastern lower Michigan. Friends of the Pleistocene Midwest Section, 30th Annual Field Conference, Guidebook, 110 pp.

Clayton, L. and Moran, S.R. (1982). Chronology of late Wisconsinan glaciation in middle North America. Quaternary Science Reviews, 1, 55-82.

Dreimanis, A. (1969). Late-Pleistocene lakes in the Ontario and the Erie basins. International Association of Great Lakes Research, Proceedings 12th Conference on Great Lakes Research, pp. $170-180$.

Dreimanis, A. (1977). Late-Wisconsin glacial retreat in the Great Lakes region, North America. New York Academy of Science, Annals, 288, 70-89.

Dreimanis, A., Terasmae, J. and McKenzie, G.D. (1966). The Port Talbot interstade of the Wisconsin glaciation. Canadian Journal of Earth Sciences, 3, 305-325.

Dreimanis, A. and Karrow, P.F. (1972). Glacial history of the Great Lakes-St. Lawrence region, the classification of the Wisconsin(an) stage, and its correlatives. International Geological Congress, 24th Session, Montreal, Section 12, Quaternary Geology, pp. 5-15.

Eschman, D.F. (1978) Pleistocene geology of the Thumb area of Michigan: Geological Society of America, North-Central Section, Ann Arbor, Guidebook, pp. 35-62.

Eschman, D.F. (1980). Some evidence of mid-Wisconsinan events in Michigan. Michigan Academician, 12, 423-436.

Eschman, D.F. (1982). An unusual ball and pillow structure locality in Michigan. Journal of Geology, 90, 742-744.

Evenson, E.B., Farrand, W.R., Eschman, D.F., Mickelson, D.M. and Maher, L.J. (1976) Greatlakean substage - A replacement for Valderan substage in the Lake Michigan basin. Quaternary Research, 6, 411-424.

Farrand, W.R., Zahner, R.F. and Benninghoff, W.S. (1969). Cary-Port Huron interstade: Evidence from a buried bryophyte bed, Cheboygan County, Michigan. Geological Society of America Special Paper 123, 249-262.

Fullerton, D.S. (1971). The Indian Castle glacial readvance in the Mohawk Lowland, New York, and its regional implications: Ph.D. dissertation, Princeton University, $270 \mathrm{pp}$.

Fullerton (1980) Preliminary correlation of post-Erie interstadial events (16,000-10,000 radiocarbon years before present), central and eastern Great Lake region, and Hudson, Champlain, and St. Lawrence Lowlands, United States and Canada. U.S. Geological Survey Professional Paper 1089, 52 pp.

Gephart, G.D., Monaghan, G.W. and Larson, G.J. (1982). A midWisconsinan event in the Lake Michigan basin [abstract]. Geological Society of America Abstracts with Programs, 14(5), 260.

Gephart, G.D. (1983) Stratigraphic evidence for a significant readvance of the Michigan ice lobe to the Kalamazoo moraine Southwestern Michigan [abstract]. Geological Society of America Abstracts with Programs, 15(5), 261.

Leverett, F. and Taylor, F.B. (1915). The Pleistocene of Indiana and Michigan and the history of the Great Lakes. U.S. Geological Survey Monograph 53, 529 pp.

Lineback, J.A., Gross, D.L. and Meyer, R.P. (1974). Glacial tills under Lake Michigan. Illinois Geological Survey Environmental Geology Note 69, $48 \mathrm{pp}$

Maher, L.J., Jr. (1981). The Green Bay sublobe began retreat 12,500 B.P.: Total pollen influx during the early Greatlakean substage (11,900 to 10,900 B.P.) was but half the influx during the Twocreekan [abstract]. Geological Society of America Abstracts with Programs, 13(6), 288.

McCartney, M.C. (1979) Stratigraphy and compositional variability of till sheets in part of northeastern Wisconsin. Ph.D. dissertation, University of Wisconsin, Madison, $147 \mathrm{pp}$.

McCartney, M.C. and Mickelson, D.M. (1982) Late Woodfordian and Greatlakean history of the Green Bay Lobe, Wisconsin. Geological Society of America Bulletin, 93, 297-302.

Mickelson, D.M., Clayton, L., Baker, R.W., Mode, W.N. and Schneider, A.F. (1984). Pleistocene stratigraphic units of Wisconsin. Wisconsin Geological and Natural History Survey Miscel. laneous Paper 84-1, 107 pp.

Need, E.A. (1983) Quaternary stratigraphy of the lower Milwaukee and Menomonee River valleys, Milwaukee, Wisconsin. Geoscience Wisconsin, 7, 24-42.

Rieck, R.L. and Winters, H.A. (1982) Low-altitude organic deposits in Michigan: Evidence for pre-Woodfordian Great Lakes and paleosurfaces. Geological Society of American Bulletin, 93 $726-734$.

Schneider, A.F. (1983). Wisconsinan stratigraphy and glacial sequence in southeastern Wisconsin. Geoscience Wisconsin, 7, 59-85.

Schneider, A.F. and Follmer, L.R. (1983a). A buried Sangamon soil in southeastern Wisconsin [abstract]. Geological Society of America Abstracts with Programs, 15(5), 262.

Schneider, A.F. and Follmer, L.R. (1983b). A buried Sangamon soil in southeastern Wisconsin. Geoscience Wisconsin, 7, 86-97.

Schneider, A.F. and Need, E.A. (1983) Lithologic and stratigraphic evidence for a late mid-Woodfordian proglacial lake in the Lake Michigan basin [abstract]. Geological Society of America Abstracts with Programs, 15(6), 680.

Stuiver, M., Huesser, C.J. and Yang, I.C. (1978). North American glacial history extended to 75,000 years. Science, 200, 16-21.

Taylor, L.D. (1977). Preliminary analysis of glacial stratigraphy in the vicinity of Port Huron and Two Rivers Till sheets, Manistee, Michigan [abstract]. Geological Society of America Abstract with Programs, 9(5), 658 .

Thwaites, F.T. (1943). Pleistocene of part of northeastern Wisconsin. Geological Society of America Bulletin, 54, 87-144.

White, O.L. and Karrow, P.F. (1971) New evidence for Spencer's Laurentian River. International Association of Great Lakes Research, Proceedings of 14th Conference on Great Lakes Research, pp. 394-400.

Zumberge, J.H. (1960). Correlation of Wisconsin drifts in Illinois, Indiana, Michigan and Ohio. Geological Society of America Bulletin, 71, 1177-1188.

Zumberge, J.H. and Benninghoff, W.S. (1969). A mid-Wisconsin peat in Michigan, United States. Pollen et Spores, 11, 585-601. 